
found.

(1) A regular "book review"-if a willing "book reviewer" can be

(2) Abstracts of suitable post-graduate theses.

(3) Page for abbreviated author's biographies.

I am pleased to report that the 1950 Chronicle, particularly the March issue, has had a number of good reviews-evidence that there are a number of articulate voices in Canadian forestry. It is not the editor but rather the contributors who establish the calibre of a technical journal, and my thanks to all those who have so willingly presented their views to the profession. My thanks also to my editorial colleagues; to those who provided valued assistance in the form of cuts (to the extent of $\$ 187.33$ ); to the president and secretary for their immense goodwill, helpful advice and continual assistance; and to all members of the Society who have so uncomplainingly absorbed the many proof-reading and other errors of the editor.

K. G. FENSOM, Editor and Chairman of the Editorial Board.

\title{
BALANCE SHEET
}

as at 31 st December, 1949

AssETs

CURrent

Cash in Bank ....................................... $1,057.32$

Accounts Receivable ...................................... 195.06

Dues Receivable .......................................... $\quad 616.00$

Investments-Government of Canada 3\% Bonds

(Par Value \$3,900.00) .............................. 4,026.75

-Accrued Interest ............................. 39.00

$39.00 \quad \$ 5,934.13$

FrXED

Office Equipment …................................... \$ $\$ 359.30$

Less: Reserve for Depreciation …….................. 120.90

238.40

OTHER

Deposit-Post Office ………........................... $\$ \$ 8.00$

Chronicle-Nominal Value ................................. 1.00

$1.00 \quad 9.00$

LIABILITIES AND SURPLUS

Current

Accounts Payable-Trade ................................\$ $\$ 110.05$

Chronicle Subscriptions Paid in Advance $1950 \ldots . . .103 .50$

Dues Paid in Advance-1950 ............................ 827.05

$\$ 1,040.60$

SURPLUS

Balance at Credit 31st December, $1948 \ldots \ldots \ldots \ldots \ldots \ldots$ \$ $\quad 4,539.60$

Add: Net Surplus for the Year

Balance at Credit 31st December, 1949

$5,140.93$

$\$ 6,181.53$

Approved: D. V. Love,

Secretary-Treasurer 
To The Members:

We have prepared the above Balance Sheet and related Statement of Revenue and Expenditure from the books and records of your society and from the information and explanations given us by responsible employees and your Secretary-Treasurer.

A complete detailed audit of all transactions was not made, but we have made sufficient tests to satisfy ourselves of the general accuracy of the accounts.

Subject to the foregoing, we are of the opinion that the above Balance Sheet and related Statement attached are properly drawn up so as to exhibit a true and correct view of the state of affairs of your Society, according to the information and explanations given to us and as shown by the books and records as at 31st December, 1949.

Toronto: 21st April, 1950

(signed) IvaN S. Gray \& CompanY Chartered Accountants STATEMENT OF REVENUE AND EXPENDITURE for the year ended 31st December, 1949

\section{REVENUE}

Dues-1949

$\$ 5,208.00$

Chronicle Subscriptions

345.62

Chronicle Advertising

Sale of Reprints

Less: Cost of Reprints

166.04

154.67

Annual Meeting Revenue

Less: Expenses

$\$ 1,759.00$

$1,537.87$

Investment Interest

Sundry Revenue

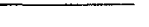

221.13

10.80

35.58

EXPENDITURE

Forestry Chronicle

Executive Honoraria

- Secretary-Treasurer

-Editor

450.00

400.00

Office Salaries

850.00

811.87

Reprints distributed to Members ......

62.10

Postage

Office Supplies

233.02

Rent

736.08

Light

256.25

Telephone and Telegraph

9.60

Sundry Expense

Fees-Canadian Council of Profes-

10.06

175.99 sional Engineers and Scientists.

94.05

Bank Charges

19.73

Travelling Expense

58.97

Depreciation-Office Equipment

29.80 